\title{
Decyzja kasacyjna organu odwoławczego w sprawie o udostępnianie informacji publicznej na wniosek
}

\author{
Wyrok Naczelnego Sądu Administracyjnego z dnia 2 kwietnia 2019 r., \\ I OSK 1283/17
}

W sytuacji, w której organ odwoławczy uzna, że decyzja organu pierwszej instancji o odmowie udostępnienia wnioskodawcy informacji publicznej nie była prawidłowa, a w sprawie zachodzą podstawy do udostępnienia informacji publicznej w formie czynności materialno-technicznej, powinien wydać decyzję o uchyleniu zaskarżonej decyzji i przekazaniu sprawy do ponownego rozpatrzenia organowi pierwszej instancji (art. 138 \& 2 k.p.a.), a nie decyzję o uchyleniu zaskarżonej decyzji i umorzeniu postępowania pierwszej instancji (art. 138 § 1 pkt 2 in fine k.p.a.).

\section{Marcin Pieńczykowski}

Wojewódzki Sąd Administracyjny w Olsztynie

marcin_pienczykowski@wp.pl

ORCID: 0000-0002-1583-0619

https://doi.org/10.26881/gsp.2020.2.14

\section{Glosa}

Komentowany wyrok ${ }^{1}$ dotyczy doniosłego procesowo zagadnienia "sposobu reakcji" organu odwoławczego na decyzję organu pierwszej instancji o odmowie udostępnienia informacji publicznej w sytuacji, w której organ odwoławczy uzna, że decyzja odmowna organu pierwszej instancji nie była prawidłowa, a w sprawie zachodzą podstawy do udostępnienia informacji publicznej w formie czynności materialno-technicznej. Wystąpienie zarysowanego zagadnienia stanowi konsekwencję niedostosowania przepisów o decyzjach kończących postępowanie odwoławcze w ogólnym postępowaniu administracyjnym (art. 138 kodeksu postępowania administracyjnego²) do specyfiki postępowania z zakresu dostępu do informacji publicznej,

\footnotetext{
1 Wyrok NSA z dnia 2 kwietnia 2019 r., I OSK 1283/17, Centralna Baza Orzeczeń Sądów Administracyjnych (CBOSA) [www.orzeczenia.nsa.gov.pl].

2 Ustawa z dnia 14 czerwca 1960 r. - Kodeks postępowania administracyjnego (tekst jedn.: Dz. U. z 2020 r., poz. 256; dalej: k.p.a.).
} 
przy jednoczesnym nieistnieniu przepisów szczególnych, które regulowałyby treść decyzji organu odwoławczego w tego rodzaju sprawach.

Owa specyfika spraw z zakresu dostępu do informacji publicznej zakłada bowiem, że udostępnienie informacji publicznej na wniosek następuje w formie czynności materialno-technicznej (tj. poza trybem postępowania administracyjnego i bez zachowania formy decyzji administracyjnej), podczas gdy odmowa udostępnienia informacji publicznej na wniosek następuje w formie decyzji administracyjnej. W efekcie - w sytuacji, w której w wyniku rozpatrzenia odwołania od decyzji o odmowie udostępnienia informacji publicznej, organ odwoławczy dochodzi do przekonania, że decyzja odmowna organu pierwszej instancji nie była prawidłowa, a w sprawie zachodzą podstawy do udostępnienia informacji publicznej (w formie czynności materialno-technicznej), rysuje się dylemat: czy uchylić decyzję organu pierwszej instancji i przekazać sprawę do ponownego rozpatrzenia organowi pierwszej instancji (co budzi zastrzeżenia, ponieważ skoro zachodzą podstawy do dokonania czynności materialno-technicznej, to żadna „sprawa”, wymagająca zachowania formy decyzji administracyjnej, nie będzie już w organie pierwszej instancji „rozstrzygana”), czy też uchylić decyzję organu pierwszej instancji i umorzyć postępowanie pierwszej instancji (co również budzi zastrzeżenia, ponieważ takie rozstrzygnięcie definitywnie kończy postępowanie administracyjne i zwalnia organ pierwszej instancji od podejmowania jakichkolwiek dalszych czynności w postępowaniu).

Ocena komentowanego wyroku Naczelnego Sądu Administracyjnego (NSA) (zawierającego rozstrzygnięcie przedstawionego zagadnienia prawnego) wymaga prezentacji - w niezbędnym zakresie - stanu sprawy.

Burmistrz, w drodze decyzji administracyjnej, odmówił wnioskodawcy udostępnienia informacji publicznej zawartej w prowadzonym przez ten organ rejestrze.

Samorządowe kolegium odwoławcze, po rozpatrzeniu odwołania wnioskodawcy, decyzją wydaną na podstawie art. $138 \S 1$ pkt 2 k.p.a. uchyliło rozstrzygnięcie organu pierwszej instancji w całości i umorzyło postępowanie pierwszej instancji w sprawie odmowy udostępnienia żądanej informacji publicznej. Kolegium wyjaśniło, że organ drugiej instancji, w sytuacji gdy - odmiennie aniżeli organ pierwszej instancji - nie znajduje podstaw do odmowy udostępnienia informacji publicznej, uchyla decyzję organu pierwszej instancji, a będąc związany treścią art. 138 k.p.a., nie może poprzestać wyłącznie na uchyleniu tego aktu (kodeks postępowania administracyjnego nie przewiduje możliwości jedynie uchylenia decyzji pierwszej instancji). Konieczne staje się - obok samego uchylenia rozstrzygnięcia organu pierwszej instancji - także umorzenie postępowania pierwszej instancji jako bezprzedmiotowego (gdyż udostępnienie informacji publicznej następuje w formie czynności materialno-technicznej, a nie w formie decyzji administracyjnej, rozstrzygającej sprawę administracyjną w trybie postępowania administracyjnego). Umorzenie postępowania nie oznacza w tym stanie rzeczy zakończenia postępowania w przedmiocie udostępnienia informacji publicznej. Otwiera ono ponownie drogę do zakończenia postępowania w przedmiocie udzielenia informacji publicznej. 
Skarżąca wywiodła skargę na rozstrzygnięcie organu odwoławczego do Wojewódzkiego Sądu Administracyjnego (WSA) w Krakowie, który wyrokiem³ z dnia 7 lutego 2017 r., uchylił decyzje zapadłe w obydwu instancjach. W ocenie WSA, zaskarżona decyzja została wydana z naruszeniem art. 138 § 1 pkt 2 i § 2 k.p.a. w związku z art. 105 § 1 k.p.a. Sąd uznał, że organ odwoławczy umorzył postępowanie w całości, co oznacza, że zwolnił organ pierwszej instancji od dalszego procedowania, w tym od pozytywnego załatwienia wniosku o udostępnienie informacji publicznej, a jak wynika z jego stanowiska zaprezentowanego w uzasadnieniu, nie to było intencją organu.

Komentowanym wyrokiem z dnia 2 kwietnia 2019 r., I OSK 1283/17, Naczelny Sąd Administracyjny oddalił skargę kasacyjną samorządowego kolegium odwoławczego od wyroku WSA w Krakowie.

Naczelny Sąd Administracyjny podniósł, że kontrowersje budzi charakter rozstrzygnięcia organu odwoławczego w razie niepodzielenia przez ten organ stanowiska wyrażonego w decyzji organu pierwszej instancji, wydanej na podstawie art. 16 ust. 1 ustawy dostępie do informacji publicznej ${ }^{4}$. Dotyczy to w szczególności sytuacji, gdy treść żądania udostępnienia informacji publicznej jest jasna i nie wymaga doprecyzowania, nie zachodzi konieczność uzupełnienia postępowania dowodowego w całości lub w znacznej części, a organ odwoławczy nie jest w posiadaniu wnioskowanej informacji i nie ma możliwości jej udostępnienia. Naczelny Sąd Administracyjny stwierdził, że postępowanie w przedmiocie udostępnienia informacji publicznej na wniosek (art. 10 u.d.i.p.) ma jednolity charakter, a w szczególności nie można w ujęciu zakresowym wyodrębnić jego części. W ocenie NSA, umorzenie postępowania w pierwszej instancji z formalnoprawnego punktu widzenia oznacza zakończenie sprawy administracyjnej będącej przedmiotem postępowania. Nie jest to - w ocenie sądu - prawidłowe rozstrzygnięcie organu odwoławczego, w przypadku gdy uzna on, że wnioskowana informacja powinna być udostępniona.

Komentowany wyrok NSA zasługuje na aprobatę.

Przede wszystkim należy wskazać, że z art. 16 ust. 2 u.d.i.p. wynika, że do decyzji odmawiającej udostępnienia informacji publicznej mają zastosowanie przepisy kodeksu postępowania administracyjnego. Przepis art. 16 ust. 2 u.d.i.p. jest jednak przepisem niekompletnym, odsyłającym jedynie sensu largo (systemowo) do innych przepisów prawa obowiązującego ${ }^{5}$.

Za trafny należy uznać wniosek, że problemy interpretacyjne związane ze stosowaniem art. 138 k.p.a. wywodzą się w szczególności właśnie z braku wskazania przez ustawodawcę w art. 16 ust. 2 u.d.i.p., że do decyzji, o których mowa w art. 16 ust. 1 u.d.i.p., przepisy k.p.a. stosuje się odpowiednio"6. Niewątpliwie zamieszczenie sformułowania o odpowiednim stosowaniu przepisów k.p.a. umożliwiłoby dostosowanie

\footnotetext{
3 Wyrok WSA w Krakowie z dnia 7 lutego 2017 r., II SA/Kr1504/16, CBOSA.

4 Ustawa z dnia 6 września 2001 r. o dostępie do informacji publicznej (tekst jedn.: Dz. U. z 2019 r., poz. 1429; dalej: u.d.i.p.).

5 Zob. H. Knysiak-Molczyk, Granice prawa do informacji w postępowaniu administracyjnym i sq̨dowoadministracyjnym, Warszawa 2013, s. 278.

6 M. Jabłoński, Udostępnianie informacji publicznej w trybie wnioskowym, Wrocław 2009, s. 239.
} 
regulacji k.p.a. do szczególnego charakteru postępowania w sprawie udostępnienia informacji publicznej’.

Jednakże specyfika decyzji wydawanych w sprawie o udostępnienie informacji publicznej, która czasem uniemożliwia stosowanie takich przepisów wprost, wydaje się przemawiać za ich odpowiednim stosowaniem ${ }^{8}$. Stąd wynika obowiązek stosowania przepisów odnoszących się wprost do decyzji administracyjnej, jak również nakaz stosowania wszelkich przepisów pozostających w związku z wydaniem decyzji; np. przepisów regulujących procedurę, która kończy się wydaniem decyzji w pierwszej instancji, jak również przepisów, które regulują możliwość skontrolowania i weryfikacji decyzjị.

Ulega również odpowiedniej modyfikacji katalog decyzji, jakie mogą zostać podjęte w toku postępowania odwoławczego ${ }^{10}$, w odniesieniu do tych, które zostały wydane przez organ pierwszej instancji na podstawie art. 16 ust. 1 u.d.i.p. Przede wszystkim w przypadku decyzji administracyjnych wydawanych na podstawie art. 16 ust. 1 u.d.i.p. organ odwoławczy nie może rozstrzygnąć w ten sposób, że uchyli decyzję organu pierwszej instancji i orzeknie co do istoty (decyzja reformatoryjna), czyli udostępni wnioskowaną informację publiczną. Takie rozstrzygnięcie nie znajduje podstaw w przepisach u.d.i.p. Organ odwoławczy nie jest bowiem dysponentem informacji publicznej, ani też udostępnienie informacji publicznej nie następuje $w$ formie decyzji administracyjnej (lecz w formie czynności materialno-technicznej); ewentualna decyzja administracyjna organu odwoławczego o udostępnieniu informacji publicznej - jako wydana bez podstawy prawnej - musiałaby zostać uznana za dotkniętą wadą uzasadniającą stwierdzenie jej nieważności (art. 156 § 1 pkt 2 k.p.a.). Katalog możliwych rozstrzygnięć organu odwoławczego w sprawach z zakresu dostępu do informacji publicznej jest zatem ograniczony i zubożony o możliwość podjęcia decyzji reformatoryjnej przez organ odwoławczy. Możliwe jest natomiast utrzymanie w mocy decyzji organu pierwszej instancji, względnie jej uchylenie i przekazanie sprawy do ponownego rozpatrzenia, a także wydanie decyzji o umorzeniu postępowania.

Problem prawny wyłania się natomiast wówczas, gdy brak jest przesłanek do wydania decyzji kasacyjnej, a jednocześnie niedopuszczalne jest wydanie decyzji reformatoryjnej ${ }^{11}$. Dotyczy to zwłaszcza sytuacji, w której - tak jak w sprawie, na tle której

\footnotetext{
7 Zob. H. Knysiak-Molczyk, Granice prawa..., s. 313.

8 Ibidem, s. 278.

9 Por. wyrok WSA w Gliwicach z dnia 7 sierpnia 2014 r., IV SA/GI 433/14, CBOSA.

10 Zgodnie z art. 138 § 1 k.p.a., organ odwoławczy wydaje decyzję, w której: 1) utrzymuje w mocy zaskarżoną decyzję albo 2) uchyla zaskarżoną decyzję w całości albo w części i w tym zakresie orzeka co do istoty sprawy (decyzja reformatoryjna) albo uchylając tę decyzję - umarza postępowanie pierwszej instancji w całości albo w części, albo 3) umarza postępowanie odwoławcze. Zgodnie z § 2, organ odwoławczy może uchylić zaskarżoną decyzję w całości i przekazać sprawę do ponownego rozpatrzenia organowi pierwszej instancji, gdy decyzja ta została wydana z naruszeniem przepisów postępowania, a konieczny do wyjaśnienia zakres sprawy ma istotny wpływ na jej rozstrzygnięcie. Przekazując sprawę, organ ten powinien wskazać, jakie okoliczności należy wziąć pod uwagę przy ponownym rozpatrzeniu sprawy.

11 Tak: wyrok WSA w Gliwicach z dnia 14 lipca 2016 r., IV SA/GI 449/16; podobnie: wyrok NSA z dnia 11 października 2017 r., I OSK 776/17, CBOSA.
} 
zapadł komentowany wyrok - organ odwoławczy uzna, że organ pierwszej instancji powinien udostępnić wnioskowaną informację publiczną i nie jest potrzebne uzupełnienie postępowania dowodowego przez ten organ.

Na tle „sposobu reakcji” organu odwoławczego w sprawach z zakresu dostępu do informacji publicznej w opisanym wyżej przypadku, w doktrynie i judykaturze zarysowały się dwa stanowiska.

Według pierwszego z nich, jeśli nie zachodzą żadne braki w zakresie postępowania dowodowego, a jedynie ma miejsce błędna ocena zebranych dowodów lub błąd w wykładni zastosowanych przepisów prawa, to niezasadne jest wydanie decyzji kasacyjnej. W sytuacji braku podstaw do odmowy udostępnienia informacji publicznej, organ odwoławczy powinien nie tylko uchylić wadliwą decyzję zapadłą w pierwszej instancji, ale zobligowany jest również umorzyć postępowanie pierwszej instancji. Umorzenie takie nie oznacza jednak zakończenia całej sprawy o udostępnienie informacji publicznej, tylko bezprzedmiotowość postępowania administracyjnego w sprawie wydania decyzji odmownej ${ }^{12}$. Umorzenie dotyczy odmowy udzielenia informacji, aktualny natomiast pozostaje wniosek o udostępnienie informacji publicznej, który powinien być rozpatrzony. W przeciwnym razie organ naraziłby się na zarzut bezczynności ${ }^{13}$.

Natomiast według drugiego stanowiska, za którym opowiedział się NSA w komentowanym wyroku, w przypadku uchylenia decyzji organu pierwszej instancji i przekazania mu sprawy do ponownego rozpoznania, jest on w dalszym ciągu zobowiązany do załatwienia wniosku i związany przepisami ustawy o dostępie do informacji publicznej. Z uwagi zaś na treść art. 138 § 2 zdanie drugie k.p.a., jest też związany oceną prawną organu odwoławczego ${ }^{14}$.

Przede wszystkim należy podnieść, że żadne z dwóch zaprezentowanych rozwiązań nie jest optymalne i nie daje w pełni satysfakcjonujących rezultatów, co zresztą podniesiono w komentowanym wyroku.

Wynika to przede wszystkim ze szczególnego charakteru uproszczonego postępowania w przedmiocie udostępniania informacji publicznej. Ze względu na niedopasowanie specyfiki rzeczonego postępowania do uregulowań kodeksu postępowania administracyjnego i brak precyzyjnych odesłań w ustawie o dostępie do informacji publicznej do konkretnych przepisów k.p.a., na tym tle pojawiają się istotne problemy prawne, m.in. omawiana kwestia wydania odpowiedniej decyzji przez organ odwoławczy.

Pomimo wielu ważkich argumentów zwolenników poglądu o potrzebie uchylenia decyzji organu pierwszej instancji i umorzenia postępowania pierwszej instancji

\footnotetext{
12 Tak: M. Jaśkowska, Dostęp do informacji publicznej w świetle orzecznictwa Naczelnego Sadu Administracyjnego, Toruń 2002, s. 70; eadem, Postępowanie w sprawie dostępu do informacji publicznej na wniosek jako rodzaj procedury hybrydowej [w:] A. Zwara, K. Bujak, M. Derlacz et al., Prawo administracyjne wobec współczesnych wyzwań. Księga jubileuszowa dedykowana profesorowi Markowi Wierzbowskiemu, Warszawa 2018, s. 234; wyrok NSA z dnia 30 marca 2011 r., I OSK 2116/10, CBOSA.

13 Zob. wyrok NSA z dnia 21 lipca 2010 r., I OSK 557/10, CBOSA.

14 Por. I. Kamińska, M. Rozbicka-Ostrowska, Art. 16 [w:] eaedem, Ustawa o dostępie do informacji publicznej. Komentarz, Warszawa 2016.
} 
(w przypadku oceny, że organ pierwszej instancji niesłusznie odmówił wnioskowanej informacji), za bardziej właściwe należy jednak uznać stanowisko opowiadające się za koniecznością uchylenia decyzji organu pierwszej instancji i przekazania sprawy do ponownego rozpatrzenia organowi pierwszej instancji na podstawie art. 138 § 2 k.p.a. (decyzja kasacyjna).

Dla wyboru prawidłowego rozstrzygnięcia organu odwoławczego w opisanej sytuacji kluczowe znaczenie ma, na co wskazał NSA w komentowanym wyroku, określenie charakteru prawnego postępowania w sprawie udostępnienia informacji publicznej.

Postępowanie w sprawie dostępu do informacji publicznej bywa określane mianem postępowania „hybrydowego"15, czyli takiego, które częściowo unormowane jest przepisami k.p.a., a częściowo pozostaje poza jego zakresem. Nie jest to z pewnością typowe postępowanie jurysdykcyjne ${ }^{16}$. Taki charakter uzyskuje ono natomiast w chwili stwierdzenia przez podmiot zobowiązany do udostępnienia informacji publicznej przesłanek do wydania decyzji o odmowie udzielenia informacji publicznej. Wydawać by się mogło, że w takim przypadku mamy do czynienia z postępowaniem składającym się z dwóch części (dwóch „faz”), przy czym pierwsza faza występuje zawsze, a druga jedynie, gdy wystąpią przesłanki wydania decyzji administracyjnej. Ta dwufazowość ma jednak charakter pozorny, w istocie postępowanie w przedmiocie udostępnienia informacji publicznej przybiera tylko jedną z dwóch postaci: postać czynności materialno-technicznej (np. udostępnienia informacji publicznej) bądź postać postępowania jurysdykcyjnego zakończonego wydaniem decyzji. W postępowaniu administracyjnym jurysdykcyjnym pozorność dotyczy pierwszej fazy postępowania, ponieważ w rzeczywistości postępowanie to już od chwili wniesienia wniosku jest postępowaniem administracyjnym jurysdykcyjnym. Okoliczność ta nie jest jednak znana wnioskodawcy, ani też podmiotowi zobowiązanemu ${ }^{17}$.

Trudność w określeniu charakteru prawnego rzeczonego postępowania polega na „pozornej zmienności” rozstrzyganej w nim sprawy ${ }^{18}$. W rzeczywistości sprawa ta nie ulega zmianie w tym postępowaniu, nie ma to miejsca również wówczas, gdy podmiot zobowiązany stwierdzi zaistnienie przesłanek do wydania decyzji o odmowie udostępnienia informacji publicznej. Przedmiotem oznaczonego postępowania administracyjnego jest w dalszym ciągu sprawa indywidualna i konkretna w podwójnym znaczeniu, tj. odnosząca się do konkretnego podmiotu oraz jego uprawnień (lub obowiązków), o których rozstrzyga władczo podmiot publiczny ${ }^{19}$. Stan faktyczny, określony w normie prawnej i obligujący do wydania decyzji w przedmiocie odmowy udostępniania informacji publicznej, istnieje zaś już od chwili wniesienia wniosku o udzielenie takiej informacji i nie ma znaczenia, że w tym momencie nie można czasami określić

\footnotetext{
15 Tak: M. Jaśkowska, Postępowanie w sprawie dostępu..., s. 219.

16 Zob. W. Jakimowicz, Adekwatność ochrony prawa do informacji publicznej do charakteru i istoty tego prawa w polskim porządku prawnym , "Casus” 2017, nr 84, s. 8.

17 Zob. H. Knysiak-Molczyk, Granice prawa..., s. 313.

18 Ibidem, s. 314.

19 J. Borkowski [w:] idem, B. Adamiak, Postępowanie administracyjne i sq̨dowoadministracyjne, Warszawa 2014, s. 163.
} 
rodzaju (postaci) postępowania uruchomionego przez żądanie udostępnienia informacji publicznejej.

Biorąc pod uwagę zaprezentowaną, ważką argumentację, trzeba skonkludować, że brak jest uzasadnionych podstaw do zakresowego dzielenia postępowania wywołanego wnioskiem o udostępnienie informacji publicznej na część, do której odnosi się decyzja organu odwoławczego rozpatrującego odwołanie od decyzji odmawiającej udostępnienia takiej informacji oraz na część, do której ta decyzja się nie odnosi²1.

W przypadku wydania decyzji kasacyjnej utrzymuje się bowiem stan rozpatrywania wniosku o udostępnienie informacji publicznej „w toku”, a ponadto organ pierwszej instancji przy ponownym jego rozpoznaniu jest związany przepisami ustawy o dostępie do informacji publicznej. Zasadne jest przyjęcie, że organ ten jest wówczas także związany oceną prawną organu odwoławczego odnośnie do niezgodności z prawem decyzji wydanej na podstawie art. 16 u.d.i.p., choć dostrzec trzeba, że wskazania organu odwoławczego mogą dotyczyć wyłącznie rezultatu w postaci uwzględnienia określonych okoliczności przy wydaniu decyzji22. Należy również zwrócić uwagę i na to, że organ pierwszej instancji, ponownie rozpoznając wniosek, musi mieć na uwadze konieczność działania zgodnego z przepisami prawa, a więc również to, by jego ewentualna kolejna decyzja odmowna nie została ponownie uchylona. W przeciwnym razie taki organ musi się liczyć z tym, co słusznie dostrzegł sąd w komentowanym wyroku, że wobec niego mogą być podjęte działania nadzorcze, a w skrajnych przypadkach prawnokarne ${ }^{23}$.

Rozważając zaś możliwość umorzenia postępowania administracyjnego przez organ odwoławczy w sprawach o udostępnienie informacji publicznej, należy mieć na uwadze, że takie umorzenie postępowania administracyjnego powinno być traktowane jako środek ostateczny, mający zastosowanie tylko w tych sytuacjach, w których nie ma możliwości podjęcia merytorycznego rozstrzygnięcia sprawy ${ }^{24}$. Decyzję o umorzeniu postępowania administracyjnego wydaje się wówczas, gdy postępowanie z jakiejkolwiek przyczyny stało się bezprzedmiotowe w całości lub w części. Bezprzedmiotowość postępowania administracyjnego, o której mowa w art. 105 § 1 k.p.a., to brak któregokolwiek z elementów materialnego stosunku prawnego i - w konsekwencji brak możliwości rozstrzygnięcia sprawy administracyjnej co do jej istoty (w sposób negatywny lub pozytywny dla strony). Co istotne, przyczyny uzasadniające umorzenie obligatoryjne nie mogą być interpretowane rozszerzająco ${ }^{25}$.

Niewątpliwie umorzenie postępowania pierwszej instancji oznacza ostateczne zamknięcie sprawy będącej przedmiotem postępowania administracyjnego, i mimo że

\footnotetext{
20 Zob. H. Knysiak-Molczyk, Granice prawa do informacji..., s. 314.

21 Podobnie: wyrok NSA z dnia 11 kwietnia 2019 r., I OSK 1343/17, CBOSA.

22 Por. K. Glibowski [w:] Kodeks postępowania administracyjnego. Komentarz, red. R. Hauser, M. Wierzbowski, Warszawa 2017, s. 1030.

23 Podobnie: I. Kamińska, M. Rozbicka-Ostrowska, Ustawa o dostępie..., s. 209.

24 Zob. wyrok NSA z dnia 9 września 1998 r., IV SA 1634/96, niepublik.

25 Zob. wyrok NSA z dnia 8 listopada 2007 r., II OSK 1161/06, CBOSA; M. Dyl [w:] Kodeks postępowania administracyjnego. Komentarz..., s. 1030.
} 
sprawa nie została merytorycznie rozpoznana, to jednak z punktu widzenia proceduralnego jest ona rozstrzygnięta i zakończona ${ }^{26}$.

Stan definitywnego rozstrzygnięcia i zakończenia sprawy z wniosku o udostępnienie informacji publicznej nie będzie zaś zachodził wówczas, gdy organ pierwszej instancji niesłusznie odmówił udostępnienia informacji publicznej; wniosek taki - po uchyleniu decyzji odmownej - nadal będzie wymagał merytorycznego rozpatrzenia i uwzględnienia a postępowanie wywołane takim wnioskiem - z praktycznego i procesowego punktu widzenia - nie będzie bezprzedmiotowe.

Owa specyficzna "jedność przeciwieństw", która wynika z istoty postępowania wywołanego wnioskiem o udostępnienie informacji publicznej, implikuje konieczność funkcjonalnej wykładni przepisów regulujących postępowanie administracyjne, w tym także przepisu art. 138 § 2 k.p.a., w taki sposób, by przepis ten najlepiej służył celowi postępowania wywołanego wnioskiem o udostępnienie informacji publicznej, niezależnie od tego, czy jest prowadzone we fragmencie prowadzącym do wydania decyzji administracyjnej, czy też we fragmencie prowadzącym do podjęcia czynności materialno-technicznej.

Z powyższych względów stanowisko wyrażone przez Naczelny Sąd Administracyjny w komentowanym wyroku należy zaaprobować.

De lege ferenda należałoby natomiast postulować stworzenie - chociażby częściowo - szczególnej regulacji procesowej uwzględniającej specyfikę spraw z zakresu dostępu do informacji publicznej. Być może uzasadnione byłoby wprowadzenie możliwości rozstrzygnięcia przez organ odwoławczy w ten sposób, że w przypadku stwierdzenia konieczności udostępnienia wnioskowanej informacji (zakończenia postępowania czynnością materialno-techniczną), uchyliłby on jedynie decyzję organu pierwszej instancji. Być może należałoby pójść jeszcze dalej i dać organowi odwoławczemu "narzędzie" w postaci zobowiązania organu pierwszej instancji do udostępnienia informacji publicznej ${ }^{27}$. Z pewnością usprawniłoby to procedowanie wniosków z zakresu dostępu do informacji publicznej i uniemożliwiłoby organom pierwszoinstancyjnym możliwość "uporczywego" odmawiania udostępniania wnioskowanych informacji publicznych.

Niewątpliwie zaś „niedopasowanie” przepisów k.p.a. do specyfiki tego rodzaju spraw stwarza problemy interpretacyjne, co potwierdza komentowany wyrok.

\section{Literatura}

Adamiak B., Borkowski J., Postępowanie administracyjne i sądowoadministracyjne, Warszawa 2014. Jabłoński M., Udostępnianie informacji publicznej w trybie wnioskowym, Wrocław 2009.

Jakimowicz W., Adekwatność ochrony prawa do informacji publicznej do charakteru i istoty tego prawa w polskim porządku prawnym ,"Casus” 2017, nr 84.

26 Zob. wyrok NSA z dnia 11 kwietnia 2019 r., I OSK 1343/17, CBOSA.

27 Podobnie: H. Knysiak-Molczyk, Granice prawa do informacji..., s. 315. 
Jaśkowska M., Dostęp do informacji publicznej w świetle orzecznictwa Naczelnego Sqdu Administracyjnego, Toruń 2002.

Jaśkowska M., Postępowanie w sprawie dostępu do informacji publicznej na wniosek jako rodzaj procedury hybrydowej [w:] Prawo administracyjne wobec współczesnych wyzwań. Księga jubileuszowa dedykowana profesorowi Markowi Wierzbowskiemu, Warszawa 2018.

Kamińska I., Rozbicka-Ostrowska M., Art. 16 [w:] eaedem, Ustawa o dostępie do informacji publicznej. Komentarz, Warszawa 2016.

Knysiak-Molczyk H., Granice prawa do informacji w postępowaniu administracyjnym i sq̨dowoadministracyjnym, Warszawa 2013.

Kodeks postępowania administracyjnego. Komentarz, red. R. Hauser, R. Wierzbowski, Warszawa 2017.

\section{Streszczenie}

\section{Marcin Pieńczykowski}

\section{Decyzja kasacyjna organu odwoławczego w sprawie o udostępnianie informacji publicznej na wniosek}

Komentowany wyrok dotyczy doniosłego procesowo zagadnienia "sposobu reakcji" organu odwoławczego na decyzję organu pierwszej instancji o odmowie udostępnienia informacji publicznej w sytuacji, w której organ odwoławczy uzna, że decyzja odmowna organu pierwszej instancji nie była prawidłowa, a w sprawie zachodzą podstawy do udostępnienia informacji publicznej w formie czynności materialno-technicznej. Wystąpienie wskazanego zagadnienia stanowi konsekwencję niedostosowania przepisów o decyzjach kończących postępowanie odwoławcze w ogólnym postępowaniu administracyjnym do specyfiki postępowania z zakresu dostępu do informacji publicznej.

Dwufazowość postępowania w przedmiocie udostępniania informacji publicznej ma charakter pozorny. Tym samym brak jest uzasadnionych podstaw do zakresowego dzielenia postępowania wywołanego wnioskiem o udostępnienie informacji publicznej.

Specyficzna "jedność przeciwieństw", która wynika z istoty postępowania wywołanego wnioskiem o udostępnienie informacji publicznej implikuje konieczność funkcjonalnej wykładni przepisów regulujących postępowanie administracyjne, w tym także przepisu art. $138 \S 2$ k.p.a., w taki sposób, by przepis ten najlepiej służył celowi postępowania wywołanego wnioskiem o udostępnienie informacji publicznej. W przypadku wydania decyzji kasacyjnej utrzymuje się stan rozpatrywania wniosku o udostępnienie informacji publicznej „w toku”, a ponadto organ pierwszej instancji przy ponownym rozpoznaniu tego wniosku jest związany przepisami ustawy o dostępie do informacji publicznej.

Dlatego też za właściwe należy uznać stanowisko, zaprezentowane przez NSA w głosowanym wyroku, opowiadające się za koniecznością uchylenia decyzji organu pierwszej instancji i przekazania sprawy do ponownego rozpatrzenia organowi pierwszej instancji na podstawie art. 138 § 2 k.p.a. (decyzja kasacyjna), w sytuacji gdy wnioskowana informacja publiczna powinna być udostępniona przez organ pierwszej instancji. 


\section{Summary}

\section{Marcin Pieńczykowski}

\section{Cassation decision of the appeal body regarding the disclosure of public information upon request}

The commented judgment concerns the procedural issue of the "way of reacting" by the appeal authority to the decision of the authority of the first instance refusing to make public information available in a situation where the appeal authority considers that the refusal decision of the authority of the first instance was not correct and there are grounds for making the public information available in the form of a substantive and technical act (not in the form of an administrative decision). The occurrence of that issue is a consequence of the failure to adapt the provisions on decisions terminating the appeal proceedings in the general administrative proceedings to the specificities of the procedure concerning the access to public information.

The author agrees with the position presented by the Supreme Administrative Court in the commented judgment, which advocates the need to repeal the first instance decision and to refer the case back to the authority of the first instance which should make the requested public information available.

Słowa kluczowe: dostęp do informacji publicznej, postępowanie administracyjne, decyzja kasacyjna

Key words: access to public information, administrative proceedings, cassation decision 